\title{
CHARACTERISTICS OF RETAIL REFRIGERATED AND NON-REFRIGERATED MARGARINES/FAT SPREADS SOLD IN MALAYSIA
}

\author{
SIVARUBY KANAGARATNAM*; TENG KIM TIU*; NUR HAQIM ISMAIL*; NORAZURA AILA MOHD \\ HASSIM*; WAN ROSNANI AWG ISA* and NOOR LIDA HABI MAT DIAN*
}

\begin{abstract}
Margarines/fat spreads are commonly consumed by Malaysians, however, these products lack documented quality characteristic information. This evaluation was aimed to determine the quality characteristics of retail refrigerated and non-refrigerated margarines/fat spreads sold in Malaysia. This evaluation was done via two approaches. The first approach was compilation and evaluation of information from the label of the product. The details evaluated were country of origin, type of packaging, weight of products, type of oils used, percentage of trans fatty acid (TFA) and type of fortification. The second approach was the analysis of the margarines/fat spreads which covered slip melting point (SMP), fatty acid composition (FAC), solid fat content (SFC) and texture. The labels showed that six out of the nine refrigerated margarines/fat spreads were imported and all non-refrigerated margarines/fat spreads were produced locally. The ingredient list showed that 16 out of 18 margarines/fat spreads from both segments declared the use of palm oil-based fats and most of the products were fortified with vitamins. The analysis showed that the SMP of refrigerated and nonrefrigerated margarines/fat spreads ranged from $30.8^{\circ} \mathrm{C}-36.9^{\circ} \mathrm{C}$ and $37.1^{\circ} \mathrm{C}-40.2^{\circ} \mathrm{C}$, respectively. The TFA level in the refrigerated and non-refrigerated margarines/fat spreads ranged from $0.25 \%-0.30 \%$ (excluding one product from Australia with 4.25\%) and from 0.16\%-0.43\%, respectively. The SFC of refrigerated products at $5{ }^{\circ} \mathrm{C}$ ranged from $11.6 \%$ and $26.4 \%$, while non-refrigerated products at $30^{\circ} \mathrm{C}$ ranged from $7.7 \%$ and $13.7 \%$. The evaluation showed that the several characteristics of the refrigerated and non-refrigerated margarines/fat spreads were substantially different despite their similar function in food applications, which were influenced by the storage temperature as the application temperatures were similar. Periodic and more extensive compilation of quality characteristic information should be carried out to provide the latest details on these products.
\end{abstract}

\section{Keywords: margarines, fat spreads, palm oil, trans fatty acids, palm solid fats.}

Received: 9 July 2020; Accepted: 24 November 2020; Published online: 23 February 2021.

\section{INTRODUCTION}

Margarines/fat spreads are commonly consumed by Malaysian, however, these products lacked the documentation of their quality characteristic

Malaysian Palm Oil Board,

6 Persiaran Institusi, Bandar Baru Bangi,

43000 Kajang, Selangor, Malaysia.

E-mail: sivaruby@mpob.gov.my information. Margarines/fat spreads are principally a substitute for dairy-based butter and are one of the fundamental ingredients of daily diets (Y1lmaz, and Ogutcu, 2015). Margarine is defined as water in oil emulsion with a minimum of $80 \%$ fat content by Food and Drug Administration (FDA), Department of Health and Human Services, USA under regulation 21CFR166.110 (FDA, 2019). The common composition of margarine is minimum of $80 \%$ fat, water is kept at a maximum of $16 \%$ and remaining $4 \%$ 
may consist of proteins, emulsifiers, salts, flavours, colours and vitamins. Whereas, the definition of fat spreads is quite ambiguous as it may contain from $25 \%-70 \%$ of fats, a concept of promoting low-fat products (Young and Wassell, 2019).

Retail margarines/fat spreads are essentially packed for household use, which functions primarily as a table spread. These products are mainly used by consumers as spreads on breads, buns and pastries. These products are also a key ingredient in the preparation and baking of biscuits, cakes, cookies, doughnuts, muffins, pastries and waffles. Margarine/fat spread functioned as aeration agent and lubricant to provide the required texture and taste (Noor et al., 2017). This versatile product is also preferred and favoured as stirfrying fat, especially for preparation of fried rice, chicken rice, fried eggs, stir-fried vegetables, fried noodles and dishes, mainly for the buttery flavour, taste and mouth-feel. Margarines/fat spreads are produced using various types of plant- and animalbased oils and fats. The plant-based oils widely used in margarines/fat spreads are palm oil and its fractions, palm kernel oil and its fractions, coconut oil and liquid oils, namely soyabean oil, sunflower oil, canola oil, olive oil, corn (maize) oil, groundnut oil and cottonseed oil (Noor et al., 2017; Ornla-ied et al., 2016; Adhikari et al., 2010a; Lakum and Sonwai, 2018; Lumor et al., 2010; Oliveira et al., 2017; Shin et al., 2010). Animal fats that are commonly used in margarines/fat spreads are beef tallow, mutton tallow, fish oil and lard (Rodriguez et al., 2001; Seriburi and Akoh, 1998; Silva et al., 2009).

Refrigerated margarines/fat spreads are stored in refrigerated condition to maintain their solid structure and texture. These products are spreadable straight out of the refrigerator (Lai et al., 2000). These margarines / fat spreads should not soften and resist oiling out when left at $21^{\circ} \mathrm{C}$ for a short period (Nor et al., 1996). Melting temperature of refrigerated margarines/fat spreads should be below body temperature and should not leave a waxy after taste in the mouth (D'Souza et al., 1992). Dropping points which indicates the melting points of the commercial refrigerated margarines/fat spreads formulated with soyabean oil and canola oil from the United States (Ohio) and Canada (Ontario) were reported to range from $27.3^{\circ} \mathrm{C}-34.2^{\circ} \mathrm{C}$. Solid fat content (SFC) of refrigerated margarines ranged from $10.9 \%-19.7 \%$ at $5^{\circ} \mathrm{C}, 8.5 \%-17.6 \%$ at $10^{\circ} \mathrm{C}$ and $9 \%-4.3 \%$ at $30^{\circ} \mathrm{C}$ (Noor and Ali, 1998; De Man et al., 1991).

Non-refrigerated margarines/fat spreads were designed to be used in tropical climate. These products are solid and spreadable at ambient temperatures which ranged from $26^{\circ} \mathrm{C}-32^{\circ} \mathrm{C}$ in Malaysia. The SMP of commercial, nonrefrigerated margarines/fat spread ranged from $38.5^{\circ} \mathrm{C}-40.1^{\circ} \mathrm{C}$ (Lai et al., 2000). Lai et al. (1999) stated that interesterified blends with SMP of $35^{\circ} \mathrm{C}-37^{\circ} \mathrm{C}$ were suitable for nonrefrigerated margarines. The SFC of these nonrefrigerated margarines/fat spreads at $30^{\circ} \mathrm{C}$ is approximately 10\% (Miskandar and Nor Aini, 2010). Reports on the characteristics of non-refrigerated margarines/fat spreads are scarce as most studies were focused on refrigerated margarines/fat spreads.

The main selection criteria of margarines/ fat spreads by consumers are health benefits, taste and convenience of use. Dietary oils and fats are a major source of energy for the human body. They are important for the maintenance of general health in adults as well as growth and development in children. Oils and fats contribute to the taste, texture, and energy content of food. In the body, lipids have many roles including a source of readily available and stored energy, a structural and functional component of all cell membranes, component of cell signalling molecules and main component in the absorption of fat-soluble vitamin.

A health concern commonly associated with margarines/fat spreads are the levels of TFA, which are formed when oils and fats are partially hydrogenated to develop hard stock fat for the manufacturing of these products (Bhardwaj et al., 2011). The World Health Organisation (WHO) calls for the elimination of industrially-produced (artificial) TFA from the global food supply by 2023. In May 2018, WHO launched a program for the progressive and effective elimination of TFA called REPLACE (which comprises the crucial stages of review, promote, legislate, assess, create and enforce). An action program which provides strategic guidance for all countries to take action toward this goal of eliminating TFA (WHO, 2020; 2019). The amount of TFA reported in refined palm oil and products ranged from 0.0\%-0.6\% (Tang, 2002; Khatoon and Reddy, 2005; Makeri et al., 2019). Palm oil, palm kernel oil, and its fractions have positioned themselves as the best commercially available solution to successfully eliminate TFA from the food chain by 2023 (Noor et al., 2017).

Refrigerated margarines/fat spreads are well documented by researchers worldwide such as Garsetti, et al. (2013) on margarines sold in USA, Vucic et al. (2015) on margarines sold in Serbia, Bentayeb et al. (2018) on margarines sold in Algeria, Abramovic et al. (2018) on margarines sold in Slovenia and Thais et al. (2020) on margarines sold in Brazil. Non-refrigerated margarines/fat spreads are widely used and unique to Malaysian consumers, however this segment of margarines / fat spreads is not well documented. Although margarines/fat spreads are widely consumed product in Malaysia, few or no focused studies have been conducted to determine their characteristics. Hence, this evaluation was aimed to determine their quality characteristics of retail refrigerated and non- 
refrigerated margarines / fat spreads sold in Malaysia.

This evaluation was done via two approaches. The first approach was compilation and evaluation of information from the label of the retail refrigerated and non-refrigerated margarines/fat spreads. The details such as country of origin, type of packaging, weight of products, type of oils used, percentage of saturated, monounsaturated, polyunsaturated TFA and type of fortification. The second approach was to determine physical and chemical characteristics such as the SMP, SFC, texture and FAC of the retail refrigerated and non-refrigerated margarines/fat spreads by carrying out the respective analysis.

\section{MATERIALS AND METHODS}

\section{Materials}

Refrigerated and non-refrigerated retail margarines/fat spreads were purchased from retail outlets such as hypermarkets, supermarkets, convenience shops and grocery shops in the vicinity of Kajang, Bangi and Putrajaya, Selangor, Malaysia. These samples represent the major brands of refrigerated and non-refrigerated margarine/ fats spreads sold in Malaysia. The products were limited to plant oil and fats based margarines and fat spreads, with exclusion of products based on butter, butter blends and animal fats. The refrigerated margarines / fat spreads were stored in cooler boxes during transportation. The expiration date of all margarines was at least three months after the date of analysis. The margarines / fat spreads were analysed within two months from the date of purchase. Three samples were bought for each brand of margarines / fat spreads. The retail refrigerated margarines/ fat spreads sample were labelled as RRM and retail non-refrigerated margarines/fat spreads sample were labelled as RNRM.

\section{Product Assessment}

The products' packaging label assessment was carried out by tabulating and evaluating details such as country of origin, type of packaging, weight of products, type of oils and fats used, percentage of fat component, TFA level and type of fortification.

\section{Slip Melting Point (SMP)}

SMP was determined by MPOB Test Method p4.2: 2004. Three capillary tubes were filled with 10 $\mathrm{mm}$ column of fat. The fat columns in the capillary tubes were chilled by rolling the ends of the tubes on a piece of ice until the column of oil solidifies. These capillary tubes were placed in a test tube and held in a beaker of water set at $10 \pm 1^{\circ} \mathrm{C}$. The beaker was then transferred to a water bath and held for $16 \mathrm{hr}$ at $10 \pm$ $1^{\circ} \mathrm{C}$. These capillary tubes were later removed from the test tube and attached to a thermometer with a rubber band, in a manner that the lower ends of the tubes were at the same level of the mercury bulb of the thermometer. Subsequently, the thermometer was suspended in a beaker containing $400 \mathrm{ml}$ of boiled distilled water with the lower end of the thermometer immersed in the water to a depth of 30 $\mathrm{mm}$. The initial temperature of the bath was adjusted from $8^{\circ} \mathrm{C}-10^{\circ} \mathrm{C}$ below the expected SMP of the fats. The water was agitated with a magnetic stirrer and heat was applied to increase the temperature at a rate of $1^{\circ} \mathrm{C} \mathrm{min}{ }^{-1}$, slowing down to $0.5^{\circ} \mathrm{C} \mathrm{min}^{-1}$ as the slip point was reached. The heating was continued until the fat column was raised. The temperature at which the fat column rose was reported as the SMP (Kuntom et al., 2005).

\section{Fatty Acid Composition (FAC)}

FAC was determined as fatty acid methyl esters (FAME). The samples $(0.05 \mathrm{~g})$ were weighed and dissolved in $1 \mathrm{ml}$ hexane. The mixture was then added with sodium methoxide $\left(\mathrm{NaOCH}_{3}\right)$ solution, $0.2 \mathrm{ml}$ of $\mathrm{NaOCH}_{3}(2 \mathrm{M})$, in anhydrous methanol and then mixed for $1 \mathrm{~min}$ with a vortex mixer. After sedimentation of sodium glycerolate, $1 \mu \mathrm{m}$ of clear supernatant was injected into Rtx 2330 fused silica capillary column $(60 \mathrm{~m} \times 0.25 \mathrm{~mm} \times 0.25 \mu \mathrm{m})($ Restex Corporation, USA) and analysed using a Burker Gas Chromatography System Model 430-GC (Burker Daltonics, USA) equipped with a flame ionisation detector (FID) and Galaxie Chromatography Data System. Injection and detection temperatures were set at $240^{\circ} \mathrm{C}$. The oven temperature was set at $190^{\circ} \mathrm{C}$. The column temperature was isothermal at $185^{\circ} \mathrm{C}$. The carrier gas was helium with a flow rate of $1 \mathrm{ml} \mathrm{min}{ }^{-1}$. The peaks were identified by comparing retention times with FAME standards and quantified using peak area normalisation methods (Kuntom et al., 2005). The fatty acid standards were from Sigma (Steinheim, Germany) and $\mathrm{NaOCH}_{3}$ solution was from Merck, Darmstadt, Germany.

\section{Solid Fat Content (SFC)}

SFC denotes the amount of solid present at a specific temperature. Determination of SFC was performed according to the MPOB Test Method p4.8: 2004 (Kuntom et al., 2005). The SFC was measured with Bruker Minispec PC 120 PulseNuclear Magnetic Resonance (p-NMR) (Karlsruhe, Germany). Samples were totally melted at $80^{\circ} \mathrm{C}$ to erase crystal memory. The totally melted samples were homogenised and filled into tubes $(10 \mathrm{~mm}$ o.d $\times 75 \mathrm{~mm}$ length) up to $3 \mathrm{~cm}$ in height. The samples were tempered at $70^{\circ} \mathrm{C}$ in a water bath for $30 \mathrm{~min}$, before chilling at $0^{\circ} \mathrm{C}$ for $90 \mathrm{~min}$. These tubes were conditioned in pre-equilibrated thermostat baths 
for 30 min prior to the measurement at the selected temperatures of $0^{\circ} \mathrm{C}, 5^{\circ} \mathrm{C}, 10^{\circ} \mathrm{C}, 15^{\circ} \mathrm{C}, 20^{\circ} \mathrm{C}, 25^{\circ} \mathrm{C}$, $30^{\circ} \mathrm{C}, 35^{\circ} \mathrm{C}, 40^{\circ} \mathrm{C}$ and $45^{\circ} \mathrm{C}$. This temperature range comprises of the SFC profile range of refrigerated $\left(5^{\circ} \mathrm{C}-25^{\circ} \mathrm{C}\right)$ and non-refrigerated margarines/ fat spreads $\left(25^{\circ} \mathrm{C}-35^{\circ} \mathrm{C}\right)$. The direct method was employed for the measurements.

\section{Texture}

Texture analyser model TA.XT.plus (Stable Microsystems, United Kingdom) was used to determine the hardness and compression values of the refrigerated and non-refrigerated margarines/ fat spreads. The puncture test was performed using a 5-mm-diameter cylindrical probe (probe P/5) with a $5 \mathrm{~kg}$ maximum load cell. A penetration distance of $12 \mathrm{~mm}$ at a pre-test speed of $1.0 \mathrm{~mm} \mathrm{~s}^{-1}$ and a posttest speed of $1.0 \mathrm{~mm} \mathrm{~s}^{-1}$ was selected and applied. The force applied was $100 \mathrm{~g}$ and the mode of testing was by compression. The texture measurements were carried out at $5^{\circ} \mathrm{C}$ for refrigerated product and $30^{\circ} \mathrm{C}$ for non-refrigerated product. The maximum force used during compression was recorded as hardness. The texture analysis graphs resulting from the penetration, plots a positive force area which provides the compression force value (Lumor et al., 2010; Vithanage et al., 2009).

\section{RESULTS AND DISCUSSION}

\section{Product Assessment Based on Label}

Selected details such as country of origin, type of packaging, weight of products (packing size), type of oils and fats used, percentage of fat component, percentage of TFA and type of fortifications are tabulated in Tables 1 and 2 .

The country of origin of the refrigerated margarines / fat spreads as shown in Table 1 indicated that five out of nine products were imported from Australia (RRM 01 to 05), one from the United Kingdom (RRM 06) and three were produced in Malaysia (RRM 07 to 09). The trend denotes that this segment was mainly dominated by imported products. These refrigerated margarines / fat spreads were packed in tubs of various sizes $(240 \mathrm{~g}, 250 \mathrm{~g}, 480$ $\mathrm{g}$ and $500 \mathrm{~g})$. Seven out of the nine products were fat spreads (RRM 01 to RRM 07) and two products were margarines (RRM 08 to RRM 09). The percentage of fat component ranged from $60.0 \%-69.0 \%$ in the Australian products, $75.0 \%$ in the United Kingdom product and $79.6 \%-82.3 \%$ for the Malaysian products, denoting that imported products had lesser fat than Malaysian products. Seven out of nine refrigerated margarines / fat spreads stated the inclusion of palm oil and/or palm kernel oil-based fats as their ingredient.
Palm oil and palm kernel oil-based fats are preferred as margarine fat as they are natural solid fat, TFA free hardstock with high oxidative stability, making it an excellent alternative to hydrogenated fats. These fats are able to provide structural character with the capability to impart the required level of plasticity and body to the margarines/fat spreads (Ghosh and Bhattacharyya, 1997; Müller et al., 1998; Ming et al., 1999; Fomuso and Akoh, 2001; Inna and Roman, 2020; Patel et al., 2016). Furthermore, the ability of palm oil to crystallise as beta prime polymorph has made it an even more appealing choice for the production of margarine fat (Saadi et al., 2010).

The TFA are of major concern in margarines / fat spreads as studies showed that TFA have adverse health effects especially on coronary heart disease (Mensink and Katan, 1990; Willett et al., 1993). The percentage of TFA stated on the labels ranged from $0.2 \%-1.5 \%$. This range excludes RRM 02 from Australia and RRM 06 from the United Kingdom as the percentage of TFA were not declared on their labels, as shown in Table 1. Most of the margarines / fat spreads were fortified with vitamins, except RRM 06 from the United Kingdom, which did not declare any type of fortification on its label. The fortification was mostly with vitamin A and D, except RRM 02 from Australia, which was fortified with only vitamin D. Fortification of Omega 3 was stated in four out of these nine products, which were two from Australia (RRM 01 and 03) and two from Malaysia (RRM 07 and 09). It is notable that RRM 08 from Malaysia was fortified with nine vitamins namely, vitamin $A, B_{1}, B_{2}, B_{6}, B_{12}, D, E$, folic acid and niacin.

Table 2 shows that all nine non-refrigerated margarines / fat spreads marketed in Malaysia were produced locally (RNRM 01 to 09), denoting that this segment is totally dominated by Malaysian products. The packaging and size of non-refrigerated margarines/fat spreads varied extensively. These non-refrigerated margarines/fat spreads were packed in tubs, tins, pails and pouch bags of various sizes/weight. The percentage of fat component varied from $78 \%-83 \%$. All the nine non-refrigerated margarines / fat spreads stated the inclusion of palm oil-based oils and fats in their formulation. Five margarines/fat spreads (RNRM 01, 02, 03, 04 and 07) have listed palm kernel oil-based fats as one of their fat components. Palm and palm kernel-based fats are able to provide the structural requirement of fats blends in margarines/fat spreads (Patel et al., 2016; Nor and Miskandar, 2007). The percentage of TFA stated on the labels ranged from $0.0 \%-0.4 \%$. RNRM 06 and 08, which were packed in pouch bags, did not declare the content of TFA on their labels. Six products were fortified with vitamins and three products which were RNRM 06, 07 and 09, packed in pouch bags, did not state any type of fortification. It 
TABLE 1. DETAILS OF REFRIGERATED MARGARINES/FAT SPREADS FROM THE PACKAGING LABEL

\begin{tabular}{|c|c|c|c|c|c|c|c|}
\hline $\begin{array}{l}\text { Margarine } \\
\text { code }\end{array}$ & $\begin{array}{c}\text { Country } \\
\text { of } \\
\text { origin }\end{array}$ & $\begin{array}{c}\text { Type of } \\
\text { packaging }\end{array}$ & $\begin{array}{l}\text { Weight } \\
\text { of } \\
\text { product }\end{array}$ & Type of oil & $\begin{array}{c}\text { Percentage } \\
\text { of fat } \\
\text { (per } 100 \mathrm{~g})\end{array}$ & $\begin{array}{l}\text { Trans fatty } \\
\text { acid } \\
\text { (per } 100 \mathrm{~g} \text { ) }\end{array}$ & Type of fortification \\
\hline RRM 01 & Australia & Tub & $500 \mathrm{~g}$ & $\begin{array}{l}\text { Vegetable oils } \\
\text { (49\% canola oil and fully } \\
\text { hydrogenated palm oil) }\end{array}$ & 63.0 & $0.2 \mathrm{~g}$ & $\begin{array}{l}\text { Vitamin A, D and } \\
\text { Omega } 3 \\
\text { (ALA: alpha linolenic } \\
\text { acid) }\end{array}$ \\
\hline RRM 02 & Australia & Tub & $\begin{array}{l}250 \mathrm{~g} \\
\text { and } \\
500 \mathrm{~g}\end{array}$ & $\begin{array}{c}\text { Vegetable oils } \\
\text { (may contain soyabean oil and } \\
\text { partially hydrogenated) }\end{array}$ & 60.0 & Not stated & Vitamin D \\
\hline RRM 03 & Australia & Tub & $500 \mathrm{~g}$ & $\begin{array}{c}\text { Sunflower, palm, rapeseed and } \\
\text { linseed oils }\end{array}$ & 69.0 & $1.0 \mathrm{~g}$ & $\begin{array}{c}\text { Vitamin A, D, } \\
\text { Omega } 3 \text { and Omega } 6\end{array}$ \\
\hline RRM 04 & Australia & Tub & $500 \mathrm{~g}$ & $\begin{array}{c}\text { Vegetable oils } \\
\text { (minimum } 20 \% \text { olive oil and fully } \\
\text { hydrogenated palm oil) }\end{array}$ & 63.0 & $0.2 \mathrm{~g}$ & itamin A and D \\
\hline RRM 05 & Australia & Tub & $500 \mathrm{~g}$ & $\begin{array}{l}\text { Vegetable oils } \\
\text { (19\% olive oil) }\end{array}$ & 65.0 & & $\operatorname{nin} A$ and $D$ \\
\hline RRM 06 & $\begin{array}{l}\text { United } \\
\text { Kingdom }\end{array}$ & Tub & $500 \mathrm{~g}$ & $\begin{array}{l}\text { Vegetable oils ( } 29 \% \text { sunflower, } \\
\text { rapeseed and palm oil) }\end{array}$ & 75.0 & & None \\
\hline RRM 07 & Malaysia & Tub & $\begin{array}{l}250 \mathrm{~g} \\
\text { and } \\
500 \mathrm{~g}\end{array}$ & $\begin{array}{l}\text { Rapeseed oil, palm fractions, } \\
\text { sunflower oil and palm kernel oil }\end{array}$ & & & $\begin{array}{c}\text { Vitamin A, D, E } \\
\text { Docosahexaenoic } \\
\text { acid (DHA), Omega } \\
3 \text { and Omega } 6\end{array}$ \\
\hline RRM 08 & Malaysia & Tub & $\begin{array}{l}240 \mathrm{~g} \\
\text { and } \\
480 \mathrm{~g}\end{array}$ & $\begin{array}{l}\text { Rapeseed oil, palm fraction, } \\
\text { soyabean oil and palm kernel oil }\end{array}$ & 82.0 & $0.7 \mathrm{~g}$ & $\begin{array}{l}\text { Vitamin } \mathrm{A}, \mathrm{B}_{1}, \mathrm{~B}_{2}, \mathrm{~B}_{6} \\
\mathrm{~B}_{12}, \mathrm{D}, \mathrm{E}, \text { folic acid } \\
\text { and niacin }\end{array}$ \\
\hline RRM 09 & Malaysia & Tub & $500 \mathrm{~g}$ & $\begin{array}{l}\text { Vegetable oils (canola and palm } \\
\text { oil) }\end{array}$ & 82.3 & $<0.5 \mathrm{~g}$ & $\begin{array}{c}\text { Vitamin A, D, E and } \\
\text { Omega } 3\end{array}$ \\
\hline
\end{tabular}

Note: RRM - Retail refrigerated margarines/fat spreads.

TABLE 2. DETAILS OF NON-REFRIGERATED MARGARINES/FAT SPREADS FROM THE PACKAGING LABEL

\begin{tabular}{|c|c|c|c|c|c|c|c|}
\hline $\begin{array}{l}\text { Margarine } \\
\text { code }\end{array}$ & $\begin{array}{l}\text { Country } \\
\text { of } \\
\text { origin }\end{array}$ & $\begin{array}{c}\text { Type of } \\
\text { packaging }\end{array}$ & $\begin{array}{l}\text { Weight of } \\
\text { product }\end{array}$ & Type of oil & $\begin{array}{c}\text { Percentage } \\
\text { of fat } \\
\text { (per } 100 \mathrm{~g} \text { ) }\end{array}$ & $\begin{array}{l}\text { Trans fatty } \\
\text { acid } \\
\text { (per } 100 \mathrm{~g})\end{array}$ & Type of fortification \\
\hline RRM 01 & Malaysia & $\begin{array}{l}\text { Tub and } \\
\text { tin }\end{array}$ & $\begin{array}{c}240 \mathrm{~g} \text { tub } \\
480 \mathrm{~g} \text { tub } \\
1.0 \mathrm{~kg} \text { tin can } \\
2.5 \mathrm{~kg} \text { tin can } \\
4.8 \mathrm{~kg} \text { pail }\end{array}$ & $\begin{array}{l}\text { Vegetable oils (palm oil, } \\
\text { palm kernel oil and fully } \\
\text { hydrogenated palm stearin) }\end{array}$ & 82.0 & $0.0 \mathrm{~g}$ & $\begin{array}{l}\text { Vitamin } \mathrm{A}, \mathrm{D}, \mathrm{E}, \mathrm{B}_{1}, \\
\mathrm{~B}_{2}, \mathrm{~B}_{3}, \mathrm{~B}_{6}, \mathrm{~B}_{12} \text {, and } \\
\text { folic acid }\end{array}$ \\
\hline RRM 02 & & & $\begin{array}{c}240 \mathrm{~g} \text { tub } \\
480 \mathrm{~g} \text { tub } \\
1.0 \mathrm{~kg} \text { tin can } \\
2.5 \mathrm{~kg} \text { tin can }\end{array}$ & $\begin{array}{l}\text { Palm oil, palm kernel oil, } \\
\text { palm fractions and partially } \\
\text { hydrogenated palm fraction }\end{array}$ & 81.4 & $0.4 \mathrm{~g}$ & $\begin{array}{l}\text { Vitamin } A, D, E \text {, } \\
\mathrm{B}_{1}, \mathrm{~B}_{2}, \mathrm{~B}_{6}, \mathrm{~B}_{12} \text {, niacin } \\
\text { and folic acid }\end{array}$ \\
\hline RRM 03 & Malaysia & Pail & $\begin{array}{l}1.0 \mathrm{~kg} \text { pail } \\
4.8 \mathrm{~kg} \text { pail }\end{array}$ & Palm oil and palm kernel oil & 78.0 & $0.0 \mathrm{~g}$ & $\begin{array}{l}\text { Vitamin } \mathrm{A}, \mathrm{D}, \mathrm{E}, \mathrm{B}_{1} \\
\mathrm{~B}_{2}, \mathrm{~B}_{6}, \mathrm{~B}_{12} \text { and niacin }\end{array}$ \\
\hline RRM 04 & Malaysia & Tub & $\begin{array}{c}240 \mathrm{~g} \text { tub } \\
480 \mathrm{~g} \text { tub } \\
2.5 \mathrm{~kg} \text { pail }\end{array}$ & Palm oil and palm kernel oil & 83.0 & $0.0 \mathrm{~g}$ & $\begin{array}{l}\text { Vitamin } A, D, E \text {, } \\
\mathrm{B}_{1}, \mathrm{~B} 2, \mathrm{~B}_{6}, \mathrm{~B}_{12}, \text { niacin } \\
\text { and folic acid }\end{array}$ \\
\hline RRM 05 & Malaysia & Tub & $250 \mathrm{~g}$ tub & $\begin{array}{l}\text { Vegetable oils and fats (palm } \\
\text { and soyabean) }\end{array}$ & 81.4 & $0.0 \mathrm{~g}$ & Vitamin A, D and E \\
\hline RRM 06 & Malaysia & $\begin{array}{l}\text { Pouch } \\
\text { bag }\end{array}$ & $\begin{array}{l}1.0 \mathrm{~kg} \text { pouch } \\
\text { bag }\end{array}$ & Oils and fats (palm) & 81.5 & Not stated & None \\
\hline RRM 07 & Malaysia & $\begin{array}{l}\text { Pouch } \\
\text { bag }\end{array}$ & $\begin{array}{l}1.0 \mathrm{~kg} \text { pouch } \\
\text { bag }\end{array}$ & $\begin{array}{l}\text { Palm oil, palm stearin and } \\
\text { palm kernel oil }\end{array}$ & 83.0 & $0.0 \mathrm{~g}$ & Vitamin E \\
\hline RRM 08 & Malaysia & $\begin{array}{l}\text { Pouch } \\
\text { bag }\end{array}$ & $\begin{array}{l}1.0 \mathrm{~kg} \text { pouch } \\
\text { bag }\end{array}$ & Palm oil and palm fraction & 82.0 & Not stated & None \\
\hline RRM 09 & Malaysia & $\begin{array}{l}\text { Pouch } \\
\text { bag }\end{array}$ & $\begin{array}{l}1.0 \mathrm{~kg} \text { pouch } \\
\text { bag }\end{array}$ & Vegetable oils and fats (palm) & 81.7 & $0.2 \mathrm{~g}$ & None \\
\hline
\end{tabular}

Note: RNRM - Retail non-refrigerated margarines/fat spreads. 
is notable that RNRM 01, 02, 03 and 04 were fortified with eight to nine vitamins namely vitamin $A, B_{1}, B_{2}$, $\mathrm{B}_{6}, \mathrm{~B}_{12}, \mathrm{D}, \mathrm{E}$, folic acid and niacin.

\section{Slip Melting Point (SMP)}

SMP is defined as the temperature at which the fats and oils have 4\% solid fat (Karabulut et al., 2004). The SMP of refrigerated margarines/fat spreads ranged from $30.8^{\circ} \mathrm{C}-36.9^{\circ} \mathrm{C}$ (Table 3 ). These products are stored in the refrigerator and are spreadable straight from the refrigerator, nevertheless, these products are required to remain stable at ambient temperatures $\left(26^{\circ} \mathrm{C}-30^{\circ} \mathrm{C}\right)$ for a short period of time. Hence, the high SMP over $30^{\circ} \mathrm{C}$ will assist the products to remain stable as well as resist structural deformation for this short period of time, when the product is exposed to ambient temperature upon usage (Nor et al., 1996).

The SMP of non-refrigerated margarines/fat spreads ranged from $37.1^{\circ} \mathrm{C}-40.2^{\circ} \mathrm{C}$ (Table 3). The higher SMP of the non-refrigerated products were essential for the products to remain stable and solid at ambient temperatures during storage and usage. In Malaysia, the ambient temperature ranges from $26^{\circ} \mathrm{C}-30^{\circ} \mathrm{C}$ throughout the year, hence, it is crucial that the SMP of these products were $5^{\circ} \mathrm{C}-12^{\circ} \mathrm{C}$ above ambient temperatures to provide structural stability (Sivaruby et al., 2013; Tang, 2019; Roseli and Akhir, 2019).

\section{Fatty Acid Composition (FAC)}

FAC of refrigerated margarines/fat spreads are shown in Table 4. The percentage of monounsaturated fatty acids (MUFA) was high, ranged from $41.86 \%-57.81 \%$. Polyunsaturated fatty acids (PUFA) percentage ranged from $15.62 \%$ $30.11 \%$. Hence, the total amount of unsaturated fatty acids (USAFA) were in the range of $62.26 \%$ -
$75.55 \%$. The high amount of unsaturated fatty acids assist in lowering the amount of solid fats at the storage temperature of $5^{\circ} \mathrm{C}$, which in turn facilitate ease of spreading. The saturated fatty acid (SAFA) percentage detected ranged from 20.28\%-35.44\%. SAFA provides the structure and functionality properties of the margarines/fat spreads (Patel et al., 2020). This range was similar to values reported by other researchers. Vucic et al. (2015) report that soft margarine from Serbia had SAFA ranging from $22.76 \%-41.09 \%$, Abramovic et al. (2018) reported the SAFA values of 29 out of 43 margarine evaluated from Solvenia ranged from $22.6 \%-39.3 \%$, Bentayeb et al. (2018) reported that SAFA of Algerian tub margarine ranged from $25.42 \%-43.55 \%$ and Thais et al. (2020) reported SAFA values ranging from $21.94 \%-31.84 \%$ in margarines/fats spreads sold in Brazil. Refrigerated margarines/fat spreads require less SAFA to acquire its spreadable texture as it is produced, transported and stored at refrigerated temperature of approximately $5^{\circ} \mathrm{C}$. The TFA of these refrigerated margarines/fat spreads ranged from $0.13 \%-0.30 \%$. However, $4.25 \%$ of TFA was detected in RRM 02, denoting that partially hydrogenated fats were used in the fat composition of this product. Abramovic et al. (2018), who evaluated TFA in margarines in Slovenia reported similar TFA values which ranged from $0.1 \%-0.8 \%$ in 41 out of 43 margarine products analysed and conversely, two margarine products had $3.1 \%$ and $6.4 \%$ of TFA. Thais et al. (2020) also reported TFA values ranging from $0.91 \%-1.62 \%$ in 11 out of 13 margarines / fats spreads sold in Brazil. The two other margarines / fats spreads had TFA values of $6.22 \%$ and $9.14 \%$, respectively. SAFA and TFA in the hardstock provide structure to margarines / fat spreads (Tekin et al., 2002; Alonso et al., 2000). RRM 01 to RRM 09 (excluding RRM 02), had SAFA ranging from $25.24 \%-35.44 \%$ with TFA ranging from $0.13 \%-0.30 \%$. Hence, principally SAFA played a dominant part as the structure provider in

TABLE 3. SLIP MELTING POINT OF REFRIGERATED AND NON-REFRIGERATED MARGARINES/FAT SPREADS

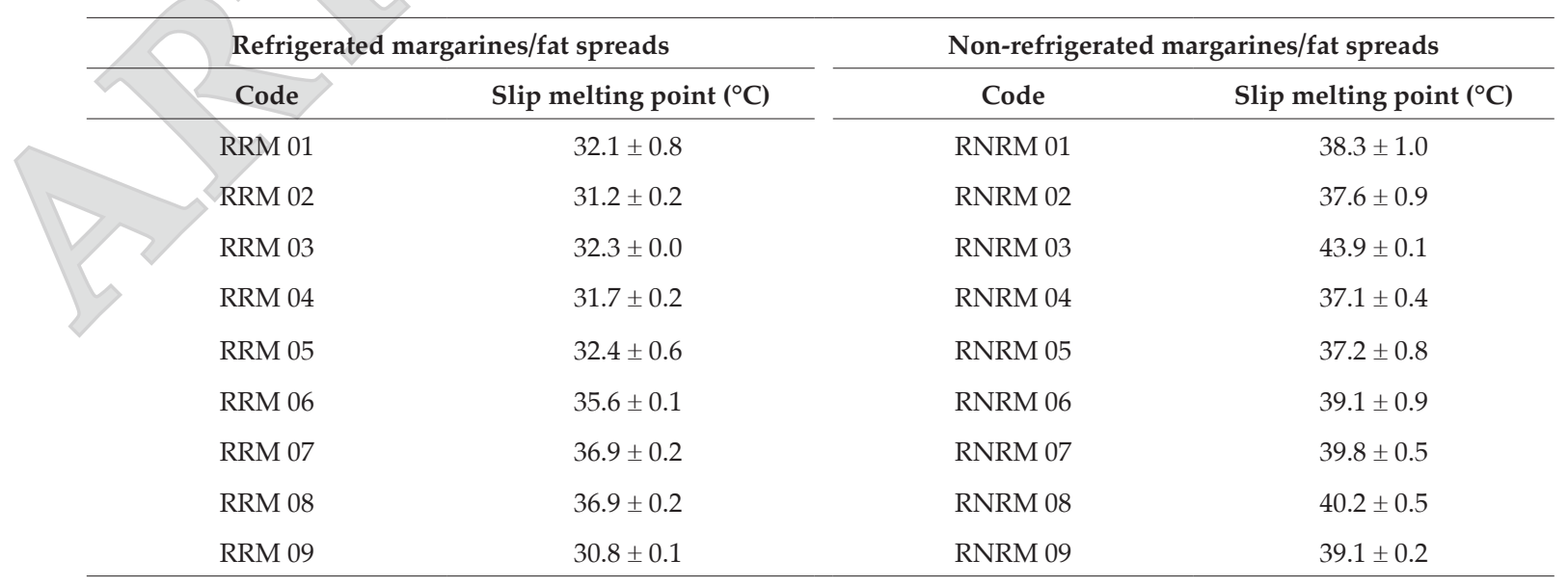

Note: RRM - Retail refrigerated margarines/fat spreads; RNRM - Retail non-refrigerated margarines/fat spreads; RRM01-05 - Australia; RRM 06 - United Kingdom; RRM 07-09 - Malaysia; RNRM 01-09 - Malaysia. 
TABLE 4. FATTY ACID COMPOSITION OF RETAIL REFRIGERATED MARGARINES/FAT SPREADS

\begin{tabular}{|c|c|c|c|c|c|c|c|c|c|}
\hline & RRM 01 & RRM 02 & RRM 03 & RRM 04 & RRM 05 & RRM 06 & RRM 07 & RRM 08 & RRM 09 \\
\hline C 8:0 & $0.26 \pm 0.00$ & $0.2 \pm 0.00$ & $0.23 \pm 0.00$ & $0.23 \pm 0.00$ & $0.14 \pm 0.01$ & $0.11 \pm 0.00$ & $0.00 \pm 0.00$ & $0.14 \pm 0.00$ & $0.00 \pm 0.00$ \\
\hline C10:0 & $0.39 \pm 0.00$ & $0.17 \pm 0.00$ & $0.28 \pm 0.00$ & $0.27 \pm 0.00$ & $0.22 \pm 0.00$ & $0.16 \pm 0.00$ & $0.00 \pm 0.00$ & $0.00 \pm 0.00$ & $0.00 \pm 0.00$ \\
\hline C12:0 & $5.75 \pm 0.02$ & $1.56 \pm 0.01$ & $4.09 \pm 0.10$ & $4.07 \pm 0.08$ & $4.47 \pm 0.24$ & $2.41 \pm 0.17$ & $0.09 \pm 0.00$ & $4.88 \pm 0.27$ & $0.04 \pm 0.00$ \\
\hline C14:0 & $2.05 \pm 0.01$ & $0.80 \pm 0.00$ & $1.55 \pm 0.07$ & $1.50 \pm 0.04$ & $1.72 \pm 0.11$ & $1.04 \pm 0.18$ & $0.31 \pm 0.01$ & $1.73 \pm 0.03$ & $0.31 \pm 0.00$ \\
\hline C16:0 & $11.30 \pm 0.11$ & $10.47 \pm 0.21$ & $9.77 \pm 0.24$ & $10.93 \pm 0.01$ & $11.52 \pm 0.29$ & $15.45 \pm 0.31$ & $14.58 \pm 0.26$ & $20.47 \pm 0.25$ & $16.2 \pm 0.21$ \\
\hline C18:0 & $7.69 \pm 0.16$ & $6.35 \pm 0.11$ & $6.82 \pm 0.20$ & $6.66 \pm 0.17$ & $6.59 \pm 0.33$ & $3.03 \pm 0.11$ & $4.07 \pm 0.09$ & $3.50 \pm 0.26$ & $2.77 \pm 0.28$ \\
\hline C 20:0 & $4.15 \pm 0.03$ & $0.51 \pm 0.02$ & $2.03 \pm 0.09$ & $1.43 \pm 0.02$ & $3.19 \pm 0.14$ & $2.94 \pm 0.11$ & $4.53 \pm 0.18$ & $4.44 \pm 0.12$ & $6.44 \pm 0.24$ \\
\hline C 22:0 & $0.27 \pm 0.00$ & $0.21 \pm 0.00$ & $0.49 \pm 0.01$ & $0.38 \pm 0.01$ & $0.33 \pm 0.01$ & $0.44 \pm 0.01$ & $0.38 \pm 0.02$ & $0.19 \pm 0.00$ & $0.23 \pm 0.00$ \\
\hline C 24:0 & $0.13 \pm 0.00$ & $0.00 \pm 0.00$ & $0.18 \pm 0.00$ & $0.13 \pm 0.01$ & $0.13 \pm 0.01$ & $0.14 \pm 0.00$ & $0.15 \pm 0.00$ & $0.09 \pm 0.00$ & $0.11 \pm 0.00$ \\
\hline SAFA & $31.98 \pm 0.21$ & $20.28 \pm 0.17$ & $25.45 \pm 0.27$ & $25.62 \pm 0.18$ & $28.30 \pm 0.29$ & $25.72 \pm 0.21$ & $24.11 \pm 0.27$ & $35.44 \pm 0.33$ & $26.1 \pm 0.29$ \\
\hline C 16:1n9 & $0.19 \pm 0.00$ & $0.16 \pm 0.00$ & $0.11 \pm 0.00$ & $0.35 \pm 0.01$ & $0.26 \pm 0.00$ & $0.13 \pm 0.00$ & $0.18 \pm 0.00$ & $0.15 \pm 0.00$ & $0.19 \pm 0.01$ \\
\hline C $18: 1 n 9$ & $40.75 \pm 0.29$ & $51.12 \pm 0.31$ & $33.69 \pm 0.23$ & $51.13 \pm 0.23$ & $45.88 \pm 0.31$ & $42.15 \pm 0.23$ & $42.06 \pm 0.32$ & $43.71 \pm 0.34$ & $56.81 \pm 0.37$ \\
\hline C $20: 1 n 9$ & $0.92 \pm 0.01$ & $0.65 \pm 0.00$ & $0.35 \pm 0.00$ & $0.32 \pm 0.00$ & $0.40 \pm 0.00$ & $0.62 \pm 0.00$ & $0.83 \pm 0.00$ & $0.47 \pm 0.00$ & $0.81 \pm 0.00$ \\
\hline MUFA & $41.87 \pm 0.31$ & $51.93 \pm 0.31$ & $34.15 \pm 0.24$ & $51.80 \pm 0.24$ & $46.54 \pm 0.31$ & $42.9 \pm 0.23$ & $43.10 \pm 0.33$ & $44.34 \pm 0.34$ & $57.81 \pm 0.38$ \\
\hline C 18:2n6 & $19.82 \pm 0.11$ & $17.71 \pm 0.01$ & $39.28 \pm 0.33$ & $21.67 \pm 0.21$ & $23.75 \pm 0.22$ & $29.84 \pm 0.32$ & $29.58 \pm 0.23$ & $18.32 \pm 0.24$ & $15.07 \pm 0.33$ \\
\hline C 18:3n3 & $0.58 \pm 0.00$ & $5.91 \pm 0.08$ & $0.33 \pm 0.00$ & $0.38 \pm 0.00$ & $0.41 \pm 0.01$ & $0.27 \pm 0.00$ & $0.52 \pm 0.00$ & $0.42 \pm 0.03$ & $0.55 \pm 0.01$ \\
\hline PUFA & $20.40 \pm 0.11$ & $23.62 \pm 0.09$ & $39.61 \pm 0.33$ & $22.04 \pm 0.23$ & $24.16 \pm 0.23$ & $30.13 \pm 0.33$ & $30.12 \pm 0.24$ & $18.75 \pm 0.27$ & $15.62 \pm 0.36$ \\
\hline C $18: 1 n 9 t$ & $0.12 \pm 0.00$ & $3.87 \pm 0.24$ & $0.14 \pm 0.00$ & $0.17 \pm 0.01$ & $0.15 \pm 0.01$ & $0.05 \pm 0.00$ & $0.00 \pm 0.00$ & $0.05 \pm 0.00$ & $0.05 \pm 0.00$ \\
\hline C 18:2n6t & $0.06 \pm 0.00$ & $0.38 \pm 0.00$ & $0.07 \pm 0.00$ & $0.08 \pm 0.00$ & $0.04 \pm 0.00$ & $0.13 \pm 0.00$ & $0.30 \pm 0.02$ & $0.19 \pm 0.01$ & $0.08 \pm 0.00$ \\
\hline TFA & $0.18 \pm 0.01$ & $4.25 \pm 0.24$ & $0.21 \pm 0.02$ & $0.25 \pm 0.01$ & $0.19 \pm 0.01$ & $0.18 \pm 0.01$ & $0.30 \pm 0.02$ & $0.24 \pm 0.01$ & $0.13 \pm 0.01$ \\
\hline
\end{tabular}

Note: RRM - Retail refrigerated margarines/fat spreads; SAFA - Saturated fatty acids; MUFA - Monounsaturated fatty acids; PUFA Polyunsaturated fatty acids; TFA - Trans fatty acid; RRM 01-05 - Australia; RRM 06 - United Kingdom; RRM 07-09 - Malaysia.

these margarines / fat spreads. On the other hand, in the case of RRM 02, the combination of SAFA and TFA of $20.28 \%$ and $4.25 \%$, respectively, provided the required structure to the fat spread.

High amounts of SAFA, ranging from $50.43 \%-59.39 \%$ were detected in non-refrigerated margarines/fat spreads (Table 5). Non-refrigerated margarines/fat spreads require higher amounts of SAFA to form and retain its solid and spreadable texture at ambient storage temperature of $26^{\circ} \mathrm{C}-30^{\circ} \mathrm{C}$. Bentayeb et al. (2018) reported that SAFA of Algerian stick margarine ranged from $46.70 \%-54.287 \%$ and Abramovic et al. (2018) reported the SAFA values of 14 out of 43 margarine evaluated from Solvenia ranged $45.0 \%-55.7 \%$. The percentage of MUFA and PUFA in these non-refrigerated margarines/fat spreads ranged from $29.50 \%-39.73 \%$ and $7.73 \%$ $12.52 \%$, respectively. Thus, the total amount of USAFA ranged from $39.90 \%-49.50 \%$. Meanwhile, the percentage of TFA ranged from $0.16 \%-0.43 \%$, indicating that partially hydrogenated fats were not used in the non-refrigerated margarines / fat spreads, which were produced in Malaysia.

\section{Solid Fat Content (SFC)}

SFC values are commonly used as indicators to characterise the physical properties of oils and fats, and their blends. Physical properties of margarines / fat spreads such as general appearance, ease of spreading (hardness), organoleptic properties (mouthfeel) and oil exudation to a great extent, is influenced by SFC (Jeung et al., 2008; Adhikari et al., 2010a, b; Noor and Ali, 1998). The SFC indicates the solid to liquid ratio or amount of fat crystals present in a fat blend at a specific temperature (Marangoni and Rousseau, 1995). Hence, SFC profile of the fat determines its usage in a particular temperature range.

The characteristic of refrigerated margarines / fat spreads which are solid (solid paste) and spreadable straight from the refrigerator $\left(5^{\circ} \mathrm{C}\right)$, is facilitated by the low percentage of $\mathrm{SFC}$ at $5^{\circ} \mathrm{C}$. The SFC of the refrigerated margarines/fat spreads at $5^{\circ} \mathrm{C}$ ranged from $11.6 \%-26.4 \%$ as shown in Figure 1. The SFC below $30 \%$ at $5{ }^{\circ} \mathrm{C}$ facilitated ease of spreading of these products straight out of refrigeration. The other crucial requirement is that these margarines / fat spreads should neither deform nor oil out at temperatures of $26^{\circ} \mathrm{C}-30^{\circ} \mathrm{C}$, which are the common usage temperatures of these products. The SFC at $25^{\circ} \mathrm{C}$ and $30^{\circ} \mathrm{C}$ ranged from $4.2 \%-6.6 \%$ and from $2.17 \%-4.93 \%$, respectively. These SFC values provide the sufficient amount of SFC in order to retain their structure and texture. These values are in line with findings reported by Nor et al. (1996) which were 3.4 
TABLE 5. FATTY ACID COMPOSITION OF RETAIL NON-REFRIGERATED MARGARINES/FAT SPREADS

\begin{tabular}{|c|c|c|c|c|c|c|c|c|c|}
\hline & RRM 01 & RRM 02 & RRM 03 & RRM 04 & RRM 05 & RRM 06 & RRM 07 & RRM 08 & RRM 09 \\
\hline C 8:0 & 0.77 & $0.74 \pm 0.04$ & $0.43 \pm 0.04$ & $0.51 \pm 0.02$ & $0.83 \pm 0.03$ & $0.75 \pm 0.02$ & $0.30 \pm 0.00$ & $0.00 \pm 0.00$ & $0.21 \pm 0.00$ \\
\hline C10:0 & 0.87 & $0.75 \pm 0.00$ & $0.66 \pm 0.00$ & $0.60 \pm 0.00$ & $1.03 \pm 0.10$ & $0.59 \pm 0.00$ & $0.42 \pm 0.00$ & $0.00 \pm 0.00$ & $0.29 \pm 0.00$ \\
\hline C12:0 & 13.47 & $12.37 \pm 0.11$ & $10.12 \pm 0.19$ & $9.73 \pm 0.20$ & $15.70 \pm 0.25$ & $2.05 \pm 0.16$ & $6.33 \pm 0.08$ & $0.23 \pm 0.00$ & $4.28 \pm 0.10$ \\
\hline C14:0 & 5.27 & $4.86 \pm 0.04$ & $4.29 \pm 0.06$ & $4.00 \pm 0.06$ & $5.76 \pm 0.09$ & $1.30 \pm 0.13$ & $2.98 \pm 0.05$ & $1.04 \pm 0.02$ & $2.30 \pm 0.07$ \\
\hline C16:0 & 33.81 & $33.71 \pm 0.30$ & $38.31 \pm 0.16$ & $37.19 \pm 0.30$ & $27.09 \pm 0.28$ & $42.99 \pm 0.28$ & $41.75 \pm 0.27$ & $44.42 \pm 0.22$ & $42.40 \pm 0.26$ \\
\hline C18:0 & 4.99 & $4.13 \pm 0.07$ & $4.15 \pm 0.09$ & $4.21 \pm 0.15$ & $5.67 \pm 0.16$ & $4.31 \pm 0.17$ & $4.34 \pm 0.10$ & $4.44 \pm 0.07$ & $4.76 \pm 0.15$ \\
\hline C 20:0 & 0.11 & $0.12 \pm 0.00$ & $0.16 \pm 0.00$ & $0.25 \pm 0.00$ & $1.27 \pm 0.05$ & $0.34 \pm 0.01$ & $0.16 \pm 0.00$ & $0.18 \pm 0.00$ & $0.16 \pm 0.00$ \\
\hline C 22:0 & 0.06 & $0.08 \pm 0.00$ & $0.06 \pm 0.00$ & $0.06 \pm 0.00$ & $0.11 \pm 0.00$ & $0.07 \pm 0.00$ & $0.06 \pm 0.00$ & $0.07 \pm 0.00$ & $0.06 \pm 0.00$ \\
\hline C 24:0 & 0.07 & $0.06 \pm 0.00$ & $0.06 \pm 0.00$ & $0.06 \pm 0.00$ & $0.07 \pm 0.00$ & $0.07 \pm 0.00$ & $0.05 \pm 0.00$ & $0.07 \pm 0.00$ & $0.06 \pm 0.00$ \\
\hline SAFA & 59.39 & $56.79 \pm 0.22$ & $58.22 \pm 0.21$ & $56.58 \pm 0.28$ & $57.51 \pm 0.26$ & $52.46 \pm 0.27$ & $56.39 \pm 0.23$ & $50.43 \pm 0.23$ & $54.50 \pm 0.00$ \\
\hline C 16:1n9 & 0.12 & $0.13 \pm 0.00$ & $0.14 \pm 0.00$ & $0.14 \pm 0.00$ & $0.11 \pm 0.00$ & $0.17 \pm 0.00$ & $0.14 \pm 0.00$ & $0.16 \pm 0.00$ & $0.15 \pm 0.00$ \\
\hline C $18: 1 n 9$ & 31.92 & $31.20 \pm 0.19$ & $33.30 \pm 0.32$ & $34.24 \pm 0.19$ & $29.20 \pm 0.22$ & $37.43 \pm 0.26$ & $34.69 \pm 0.25$ & $39.43 \pm 0.31$ & $36.10 \pm 0.22$ \\
\hline C 20:1n9 & 0.13 & $0.13 \pm 0.00$ & $0.13 \pm 0.00$ & $0.14 \pm 0.00$ & $0.19 \pm 0.00$ & $0.14 \pm 0.00$ & $0.13 \pm 0.00$ & $0.14 \pm 0.00$ & $0.13 \pm 0.00$ \\
\hline MUFA & 32.17 & $31.45 \pm 0.22$ & $33.57 \pm 0.33$ & $34.53 \pm 0.20$ & $29.90 \pm 0.24$ & $37.83 \pm 0.28$ & $34.98 \pm 0.27$ & $39.73 \pm 0.32$ & $36.38 \pm 0.23$ \\
\hline C 18:2n6 & 7.42 & $9.17 \pm 0.11$ & $7.35 \pm 0.09$ & $7.78 \pm 0.16$ & $12.21 \pm 0.22$ & $9.56 \pm 0.19$ & $7.90 \pm 0.10$ & $9.40 \pm 0.21$ & $8.27 \pm 0.18$ \\
\hline C 18:3n3 & 0.31 & $0.29 \pm 0.00$ & $0.31 \pm 0.00$ & $0.34 \pm 0.00$ & $0.31 \pm 0.00$ & $0.34 \pm 0.01$ & $0.32 \pm 0.00$ & $0.37 \pm 0.01$ & $0.33 \pm 0.00$ \\
\hline PUFA & 7.73 & $9.46 \pm 0.09$ & $7.66 \pm 0.10$ & $8.12 \pm 0.17$ & $12.52 \pm 0.23$ & $9.90 \pm 0.20$ & $8.22 \pm 0.11$ & $9.77 \pm 0.20$ & $8.60 \pm 0.20$ \\
\hline C $18: 1 n 9 t$ & 0.08 & $0.25 \pm 0.00$ & $0.07 \pm 0.00$ & $0.00 \pm 0.00$ & $0.35 \pm 0.01$ & $0.08 \pm 0.00$ & $0.05 \pm 0.00$ & $0.07 \pm 0.00$ & $0.07 \pm 0.00$ \\
\hline C $18: 2 \mathrm{n} 6 \mathrm{t}$ & 0.18 & $0.13 \pm 0.00$ & $0.09 \pm 0.00$ & $0.09 \pm 0.00$ & $0.08 \pm 0.00$ & $0.14 \pm 0.00$ & $0.11 \pm 0.00$ & $0.11 \pm 0.00$ & $0.10 \pm 0.00$ \\
\hline TFA & 0.26 & $0.37 \pm 0.01$ & $0.16 \pm 0.01$ & $0.09 \pm 0.00$ & $0.43 \pm 0.02$ & $0.21 \pm 0.00$ & $0.16 \pm 0.00$ & $0.18 \pm 0.00$ & $0.17 \pm 0.01$ \\
\hline
\end{tabular}

Note: RRM - Retail refrigerated margarines/fat spreads; SAFA - Saturated fatty acids; MUFA - Monounsaturated fatty acids; PUFA Polyunsaturated fatty acids; TFA - Trans fatty acid; RRM 01-05 - Australia; RRM 06 - United Kingdom; RRM 07-09 - Malaysia.

to 7.2 at $30^{\circ} \mathrm{C}$. The SFC profiles of these refrigerated margarines / fat spreads enable these products to be spreadable at refrigeration temperatures as well as retaining its structure without any deformities when exposed to ambient temperatures for a short period during usage (Cheong et al. 2009). Karabulut et al. (2004) stated that the waxy aftertaste in the mouth could be avoided if the margarine had SFC below $3.5 \%$ at $33.3^{\circ} \mathrm{C}$ and melting completely at body temperature. Tekin et al. (2002) reported SFC of 1.8 to 3.1 at $33.3^{\circ} \mathrm{C}$ of retail margarine and Karabulut and Turan (2006) reported SFC values of 0.0 to 3.6 at $35^{\circ} \mathrm{C}$ for retail tub margarine. Figure 1 showed that the SFC of all nine refrigerated margarines / fat spreads were below $2.5 \%$ at $35^{\circ} \mathrm{C}$, hence enabling elimination of waxy aftertaste in the mouth.

Non-refrigerated margarines/fat spreads had a higher SFC profile than refrigerated margarines / fat spreads, as these type of products are used and stored at ambient temperature of between $25^{\circ} \mathrm{C}-30^{\circ} \mathrm{C}$ (Tang, 2019; Roseli and Akhir, 2019). The SFC of RNRM as shown in Figure 2. The SFC of RNRM at $25^{\circ} \mathrm{C}$ and $30^{\circ} \mathrm{C}$ ranged from $11.4 \%-19.7 \%$ and from $7.71 \%-13.66 \%$, respectively. The SFC of non-refrigerated margarines/fat spreads below $20 \%$ enables it to be spreadable at $25^{\circ} \mathrm{C}$. The SFC at $40^{\circ} \mathrm{C}$ ranged from $2.89 \%-6.7 \%$, of which this high SFC values assisted non-refrigerated margarines / fat spreads to retain its structure and texture at this temperature.

\section{Texture}

Texture is defined as sensorial and functional characteristic of the structural, mechanical, and surface properties of foods that can be identified by senses of sight (visual texture), sound (auditory texture), touch (tactile texture) and kinesthetics (Szczesniak, 2002). Margarines/fat spreads are served to consumers with solid paste texture. This texture is an important property of margarines/ fat spreads as it facilitates their spreading ability which strongly influences the perceived quality of these food products (Yilmaz and Ogutcu, 2015). The sensory attributes such as spreadability, mouthfeel and texture of the food containing significant amount of fats are dependent on the microstructural properties of the fat system (Campos et al., 2002; Narine and Marangoni, 1999a, b, c) and processing parameters (Lefebure et al., 2013; Soronja-Simovic et al., 2017). Spreadability, which is the crucial rheological property of these products, is mainly dependent on the composition of fat blends that is influenced by SFC and morphology of the fat crystal network and dictated by the processing parameter applied (DeMan et al., 1991; Campos et al., 2002; 


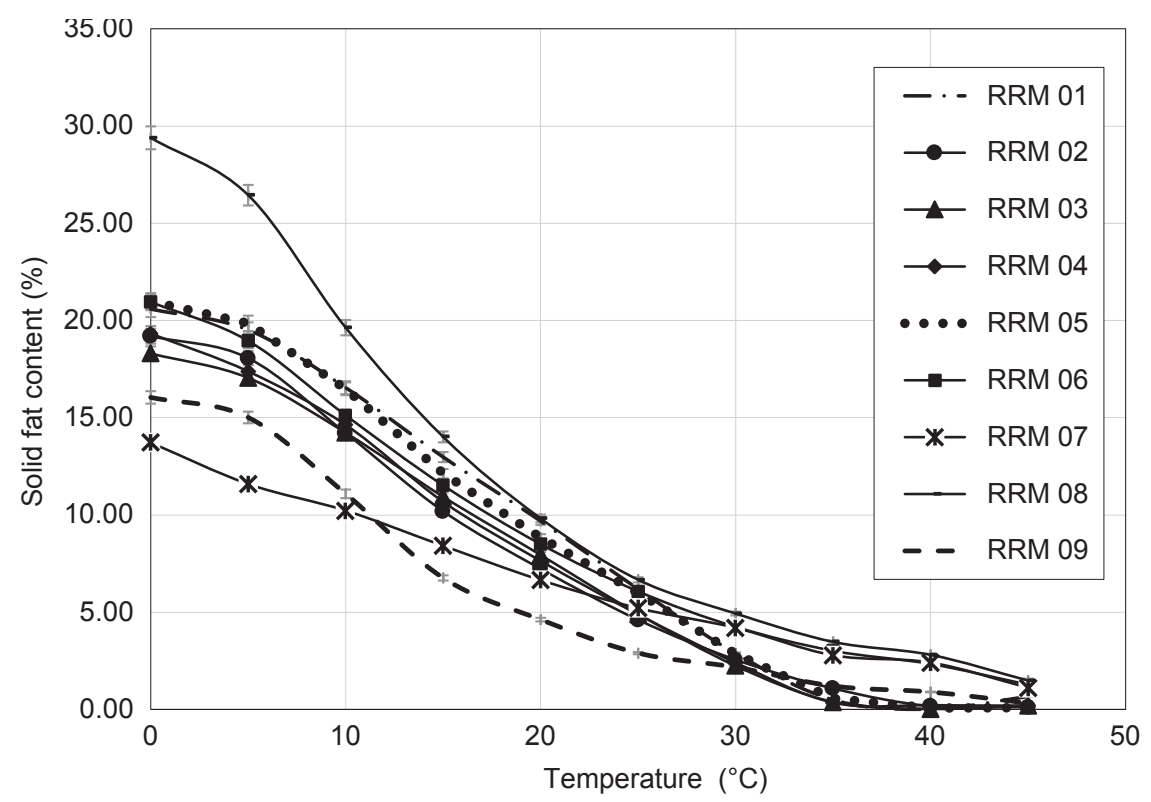

Note: RRM 01-05 - Australia; RRM 06 - United Kingdom; RRM 07-09 - Malaysia; RRM - Retail refrigerated margarines/fat spreads.

Figure 1. Solid fat content profile of retail refrigerated margarines/fat spreads.

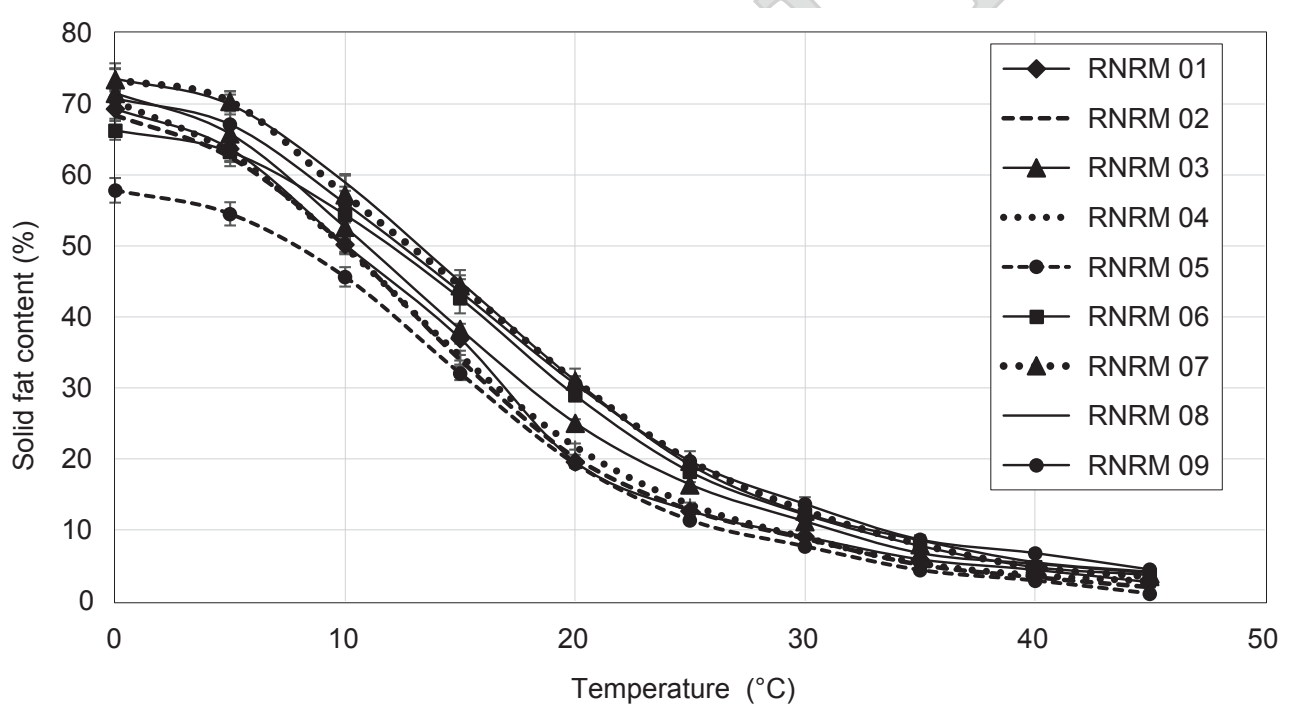

Note: RNRM - Retail non-refrigerated margarines / fat spreads; RRM 01-09 - Malaysia.

Figure 2. Solid fat content profile of retail non-refrigerated margarines/fat spreads.

Tang and Marangoni, 2007). Hence, spreadability of these products is significantly influenced by the hardness and compression values of the margarines / fat spreads at a specific temperature. The increase in hardness and compression values relates to the difficulty in spreading (Davey and Jones, 1985). The compression or cohesiveness (consistency) is a measure of intermolecular strength, indicating the strength of internal bonds making up the body of the food and the degree to which it can be deformed (Rodriguez et al., 2001).

Tables 6 and 7 show the hardness and compression values of refrigerated and non-margarines/fat spreads from texture analysis carried out at $5^{\circ} \mathrm{C}$ and $30^{\circ} \mathrm{C}$, accordingly. The hardness and compression values (reflect consistency) of refrigerated margarines/fat spreads at $5^{\circ} \mathrm{C}$ ranged from 61.41 $\pm 1.29 \mathrm{~g}$ to $366.98 \pm 9.63 \mathrm{~g}$ and from $617.64 \pm 13.81$ $\mathrm{g} \mathrm{s}^{-1}$ to $3016.64 \pm 654.38 \mathrm{~g} \mathrm{~s}^{-1}$. It was observed that these ranges of hardness and compression values facilitated spreading of refrigerated margarines/fat spreads straight from the refrigeration temperature of $5^{\circ} \mathrm{C}$. On the other hand, the hardness and compression values of non-refrigerated margarines / fat spreads at $30^{\circ} \mathrm{C}$ (stored and used temperature) ranged from $38.06 \pm 0.45 \mathrm{~g}$ to $273.97 \pm 3.42 \mathrm{~g}$ and 
TABLE 6. TEXTURE PROPERTIES OF HARDNESS AND COMPRESSION OF REFRIGERATED MARGARINES/FAT SPREADS AT $5^{\circ} \mathrm{C}$

\begin{tabular}{lcc}
\hline Code & $\begin{array}{c}\text { Hardness } \\
(\mathbf{g})\end{array}$ & $\begin{array}{c}\text { Compression } \\
\left(\mathbf{g ~ s}^{-1}\right)\end{array}$ \\
\hline RRM 01 & $90.15 \pm 3.25$ & $79.794 \pm 44.11$ \\
RRM 02 & $102.98 \pm 2.44$ & $978.89 \pm 32.24$ \\
RRM 03 & $143.77 \pm 1.72$ & $1387.48 \pm 44.30$ \\
RRM 04 & $254.22 \pm 0.66$ & $1305.78 \pm 130.79$ \\
RRM 05 & $220.78 \pm 2.75$ & $1847.15 \pm 70.25$ \\
RRM 06 & $239.40 \pm 4.61$ & $2037.01 \pm 214.69$ \\
RRM 07 & $61.41 \pm 1.29$ & $617.64 \pm 13.81$ \\
RRM 08 & $366.98 \pm 9.63$ & $3016.64 \pm 654.38$ \\
RRM 09 & $257.52 \pm 17.70$ & $2158.76 \pm 255.14$ \\
\hline
\end{tabular}

Note: RRM - Retail refrigerated margarines/fat spreads; RRM 01-05 - Australia; RRM 06 - United Kingdom; RRM 07-09 - Malaysia.

TABLE 7. TEXTURE PROPERTIES OF HARDNESS AND COMPRESSION OF NON-REFRIGERATED MARGARINES/ FAT SPREADS AT $30^{\circ} \mathrm{C}$

\begin{tabular}{lcc}
\hline Code & $\begin{array}{c}\text { Hardness } \\
(\mathbf{g})\end{array}$ & $\begin{array}{c}\text { Compression } \\
\left(\mathrm{g} \mathrm{s}^{-1}\right)\end{array}$ \\
\hline RNRM 01 & $38.06 \pm 0.45$ & $328.011 \pm 2.31$ \\
RNRM 02 & $68.64 \pm 2.49$ & $665.39 \pm 17.91$ \\
RNRM 03 & $135.71 \pm 0.76$ & $1353.86 \pm 41.57$ \\
RNRM 04 & $88.87 \pm 2.21$ & $871.72 \pm 107.24$ \\
RNRM 05 & $39.71 \pm 0.34$ & $367.26 \pm 5.94$ \\
RNRM 06 & $164.81 \pm 4.85$ & $1578.93 \pm 21.56$ \\
RNRM 07 & $155.52 \pm 3.26$ & $1557.09 \pm 39.30$ \\
RNRM 08 & $273.97 \pm 3.42$ & $1929.41 \pm 140.65$ \\
RNRM 09 & $269.64 \pm 5.42$ & $2051.99 \pm 141.83$ \\
\hline
\end{tabular}

Note: RNRM - Retail non-refrigerated margarines/fat spreads; RNRM 01-09 - Malaysia.

from $328.01 \pm 2.31 \mathrm{~g}$ to $2051 \pm 141.83 \mathrm{~g}$, respectively. The hardness and compression values of nonrefrigerated margarines/fat spreads at $30^{\circ} \mathrm{C}$ were lower than the values of refrigerated margarines/ fat spreads at $5^{\circ} \mathrm{C}$, indicating softer product at application temperature.

It was observed that the products packed in tins, tubs and pails were softer than those packed in pouch bags. Non-refrigerated margarines/fat spreads filled in tubs, tins and pails had hardness and compression values ranging from $38.06 \pm$ $0.45 \mathrm{~g}$ to $135.71 \pm 0.76 \mathrm{~g}$ and from $367.26 \pm 5.94 \mathrm{~g}$ $\mathrm{s}^{-1}$ to $1353.86 \pm 41.57 \mathrm{~g} \mathrm{~s}^{-1}$, respectively and nonrefrigerated margarines/fat spreads packed in pouch bags had hardness and compression values ranged from $155.52 \pm 3.26 \mathrm{~g}$ to $273.97 \pm 3.42 \mathrm{~g}$ and from $1557.09 \pm 39.30 \mathrm{~g} \mathrm{~s}^{-1}$ to $2051.99 \pm 141 \mathrm{~g} \mathrm{~s}^{-1}$, respectively. This is due to the fact that margarines/ fat spreads in the pouch bags need to withstand pressure during transportation and storage without deformation as the packaging material was merely a thin film of plastic (low density polyethylene, LDPE) as compared to tins, tubs and pails, which were able to provide better protection to the products.

Hardness and compression values of the refrigerated and non-refrigerated margarines/fat spreads did not show direct association with the SMP, SFC and FAC of these products. Braipson and Deroanne (2004) also found no linear relationship between hardness and SFC. Variation in hardness and compression value must be due to the variation in the processing conditions, which determines the crystal structure and network that establishes the strength of the texture (Young and Wassell, 2019; Di Bari et al., 2014; DeMan et al., 1991).

\section{CONCLUSION}

The characteristics of refrigerated and nonrefrigerated margarines/fat spreads sold in Malaysia varied substantially, as the products were influenced by the temperature at which these products were stored. In this evaluation, two approaches were carried out to determine the variation between refrigerated and non-refrigerated margarines/fat spreads sold in Malaysia. The first approach was the evaluation of the information on the labels of the products. Details from the labels denote that the refrigerated margarines/fat spreads were dominated by imported products while all the non-refrigerated margarines/fat spreads were produced locally. Palm oil- and palm kernel-based oils were used as fat components in seven out of nine refrigerated and all nine non-refrigerated margarines / fat spreads. Hence, palm oil-based fats are the preferred fat in this product. Palm oil-based fats are able to deliver the functionality of partially hydrogenated fats in margarines / fat spreads, hence drastically reducing TFA. Most of the refrigerated and non-refrigerated margarines/fat spreads were fortified with vitamins. Refrigerated margarines/ fat spreads were packed in tubs while the nonrefrigerated margarines / fat spreads were packed in tubs, tins, pails, and pouch bags of various sizes/ weight. The variation in packing size denoted that non-refrigerated margarines/fat spreads had a wider consumer base which included small food and catering business.

The second approach was the analyses of refrigerated and non-refrigerated margarines/fat spreads. The refrigerated margarines/fat spreads had lower SMP than the non-refrigerated products. The SMP values reflected lower SAFA and higher USAFA contents in refrigerated margarines/fat spreads compared to non-refrigerated products. Both refrigerated and non-refrigerated margarines / fat spreads contained very low level of TFA having value of less than $0.43 \%$ (exception to refrigerated 
margarine from Australia, RRM 02 with $4.25 \%$ of TFA) as most of products which declared the use of palm oil- and palm kernel-based oils had low TFA levels. The refrigerated margarines / fat spreads were spreadable with SFC of $11.6 \%$ to $26.4 \%$ and hardness values of $61.41 \mathrm{~g}$ to $366.98 \mathrm{~g}$ at $5^{\circ} \mathrm{C}$, while the non-refrigerated margarines/fat spreads were spreadable with SFC of $7.71 \%-13.66 \%$ and hardness values of $38.06 \mathrm{~g}$ to $273.97 \mathrm{~g}$ at $30^{\circ} \mathrm{C}$. This evaluation shows that the variation in SMP, SFC, hardness, and compression values of refrigerated and nonrefrigerated margarines / fat spreads were important attributes providing the required structure at the storage and usage temperature. This evaluation was able to provide information on the segment of non-refrigerated margarines/fat spreads which were produced and sold in Malaysia. Periodic compilation on quality characteristics information should be carried out in order to have the latest details on these products.

\section{ACKNOWLEDGEMENT}

The authors would like to thank the management of MPOB for permission to execute and publish this work. The authors would also like to thank the staff of Food Technology Group, Che' Maimon Che Ha, Ramlah Ahmad, Abd. Nasoikheiddinah and Rosnani Osman for their support.

\section{REFERENCES}

Abramovic, H; Vidrih, R; Zlatic, E; Kokalj, D; Schreiner, M; Zmitek, K and Pravst, I (2018). Trans fatty acids in margarines and shortenings in the food supply in Slovenia. J. Food Composition and Analysis, 74: 53-63.

Adhikari, P; Shin, J A; Lee, J H; Hu, J N; Zhu, X M; Akoh, C C and Lee, K T (2010a). Production of transfree margarine stock by enzymatic interesterification of rice bran oil, palm stearin and coconut oil. J. Science of Food and Agriculture, 90: 703-711.

Adhikari, P; Zhu, X M; Gautam, A; Shin, J A; Hu, J N; Lee, J H; Akoh, C C and Lee, K T (2010b). Scaledup production of zero-trans margarine fat using pine nut oil and palm stearin. Food Chemistry, 119: $1332-1338$.

Alonso, L; Fraga M J and Juarez, M (2000). Determination of trans fatty acids and fatty acid profiles in margarines marketed in Spain. J. Amer. Oil Chem. Soc., 77: 131-136.

Bentayeb, A L S; Mekimene, L; Mazi, D; Hamidchi, T; Hadjal, S; Boualit, S and Benalia, M(2018). Nutritional quality and safety of Algerian margarines: Fatty acid composition, oxidative stability and physicochemical properties. Mediterranean J. Nutrition and Metabolism, 11: 331-342.

Bhardwaj, S; Passi, S J and Misra, A (2011). Overview of trans fatty acids: Biochemistry and health effects. Diabetes and Metabolic Syndrome: Clinical Research and Reviews, 5: 161-164.

Braipson, D S and Deroanne, C (2004). Influence of SFC, microstructure and polymorphism on texture (hardness) of binary blends of fats involved in the preparation of industrial shortenings. Food Research International, 37: 941-948.

Campos, R; Narine, S S and Marangoni, A G (2002). Effect of cooling rate on the structure and mechanical properties of milk fat and lard. Food Research International, 35: 971-981.

Cheong, L Z; Tan, C P; Long, K; Suria, A Y M and Lai, O M (2009). Physicochemical, textural and viscoelastic properties of palm diacylglycerol bakery margarine during storage. J. Amer. Oil Chem. Soc., 86: 723-731.

Davey, K R and Jones, P N (1985). Evaluation of a sliding pin consistometer for measurement of the hardness and spreadability of butter and margarine. J. Texture Studies, 16: 75-84.

DeMan, L; Shen, C F and DeMan, J M (1991). Composition, physical and textural characteristics of soft (tub) margarines. J. Amer. Oil Chem. Soc., 68: 70-73.

Di Bari, V; Norton, J E and Norton, I T (2014). Effect of processing on the microstructural properties of water-in-cocoa butter emulsions. J. Food Engineering 122: 8-14.

D'Souza, V; DeMan, J M and DeMan, L (1992). Chemical and physical properties of the solid fats in commercial soft margarines. J. Amer. Oil Chem. Soc., 69: 1198-1205.

Davey, K R and Jones, P N (1985). Evaluation of a sliding pin consistometer for measurement of the hardness and spreadability of butter and margarine. J. Texture Studies, 16: 75-84.

FDA (2019). Food and Drugs Administration the United States of America, 21 Code of Federal Regulation, Part 166 Margarine (revised 1 April 2019). FDA 21CFR166.110.

Fomuso, L B and Akoh, C C (2001). Enzymatic modification of high-laurate canola to produce 
margarine fat. J. Agricultural and Food Chemistry, 49: 4482-4487.

Garsetti, M; Balentine, D A; Zock, P L; Blom, W A M and Wanders, A J (2013). Fat composition of vegetable oil spreads and margarines in the USA in 2013: A national market place analysis. Int. J. Food Sciences and Nutrition, 67: 372-382.

Ghosh, S and Bhattacharyya, D K (1997). Utilization of high-melting palm stearin in lipase-catalyzed interesterification with liquid oils. J. Amer. Oil Chem. Soc., 74: 589-592.

Inna, S and Roman, P (2020). Imports and use of palm oil as a way to increase safety of food fats. Handbook of Research on Globalized Agricultural Trade and New Challenges for Food Security. IGI Global. Hershey, PA, USA. p. 277-295.

Jeung, H L; Akoh, C C; Himmelsbach, D S and Lee, K T (2008). Preparation of interesterified plastic fats from fats and oils free of trans fatty acid. J. Agricultural and Food Chemistry, 56: 4039-4046.

Karabulut, I and Turan, S (2006). Some properties of margarines and shortenings marketed in Turkey. J. Food Composition and Analysis, 19: 55-58.

Karabulut, I; Turan, S and Ergin, G (2004). Effects of chemical interesterification on solid fat content and slip melting point of fat/oil blends. European Food Research and Technology, 218: 224-229.

Khatoon, S and Reddy, S R Y (2005). Plastic fats with zero trans fatty acids by interesterification of mango, mahua and palm oils. European J. Lipid Science and Technology, 107: 786-791.

Kuntom, A; Siew, W L; Tan, Y A; Nor, A I and Ibrahim, N A (2005). MPOB Test Methods. MPOB, Bangi. p. 366-374.

Lai, O M; Ghazali, H M; Cho, F and Chong, C L (2000). Physical and textural properties of an experimental table margarine prepared from lipasecatalysed transesterified palm stearin: Palm kernel olein mixture during storage. Food Chemistry, 71: 173-179.

Lai, O M; Ghazali, H M and Chiew Let, C (1999). Use of enzymatic transesterified palm stearin-sunflower oil blends in the preparation of table margarine formulation. Food Chemistry, 64: 83-88.

Lakum, R and Sonwai, S (2018). Production of transfree margarine fat by enzymatic interesterification of soy bean oil, palm stearin and coconut stearin blend. Int. J. Food Science and Technology, 53: 2761-2769.
Lefebure, E; Ronkart, S; Brostaux, Y;Bera, F; Blecker, C and Danthine, $S$ (2013). Investigation of the influence of processing parameters on physicochemical properties of puff pastry margarines using surface response methodology. LWT - Food Science and Technology 51: 225-232.

Lumor, S E; Pina-Rodriguez, A M; Shewfelt, R L and Akoh, C C (2010). Physical and sensory attributes of a trans-free spread formulated with a blend containing a structured lipid, palm mid-fraction and cottonseed oil. J. Amer. Oil Chem. Soc., 87: 69-74.

Makeri, M; Sahri, M M; Ghazali, H M; Ahmad, K and Muhammad, K (2019). Polymorphism, textural and crystallization properties of winged bean (Psophocarpus tetragonolobus, D C) oil-based transfatty acids free ternary margarine blends. LWT - Food Science and Technology, 100: 158-166.

Marangoni, A G and Rousseau, D R (1995). Engineering triacylglycerols: The role of interesterification. Trends in Food Science and Technology, 6: 329-335.

Mensink, R P and Katan, M B (1990). Effect of dietary trans fatty acids on high-density and low-density lipoprotein cholesterol levels in healthy subjects. New England J. Medicine, 323: 439-445.

Miskandar, M S and Nor, A I (2010). Palm stearin as low trans hard stock for margarine. Sains Malaysiana, 39: 821-827.

Narine, S S and Marangoni, A G (1999a). Microscopic and rheological studies of fat crystal networks. J. Crystal Growth, 198/199: 1315-1319.

Narine, S S and Marangoni, A G (1999b). Relating structure of fat crystal networks to mechanical properties: A review. Food Research International, 32: 227-248.

Narine, S S and Marangoni, A G (1999c). Factors affecting the texture of plastic fats. Int. News on Fats, Oils and Related Materials, 10: 565-570.

Noor, L M D; Rafidah, A H; Sivaruby, K; Wan, R I A; Norazura, A M H; Nur, H I; Zaliha, O and Miskandar, M S (2017). Palm oil and palm kernel oil: Versatile ingredient for food applications. J. Oil Palm Res. Vol. 29(4): 487-511.

Noor Lida, H M D and Ali, A R M (1998). Physicochemical characteristics of palm-based oil blends for the production of reduced fat spreads. J. Amer. Oil Chem. Soc., 75: 1625-1631.

Nor, A I; DeMan, L; Tang, T S and Chong, C L (1996). Chemical composition and physical properties of 
soft (tub) margarines sold in Malaysia. J. Amer. Oil Chem. Soc., 73: 995-1001.

Nor, A I and Miskandar, M S (2007). Utilization of palm oil and palm products in shortenings and margarines. European J. Lipid Science and Technology, 109: 422-432.

Oliveira, P D; Rodrigues, A M C; Bezerra, C V and Silva, L H M (2017). Chemical interesterification of blends with palm stearin and patawa oil. Food Chemistry, 215: 369-376.

Ornla-Ied, P; Sonwai, S and Lertthirasuntorn, S (2016). Trans-free margarine fat produced using enzymatic interesterification of rice bran oil and hard palm stearin. Food Science and Biotechnology, 25: 673-680.

Patel, A R; Lecerf, J M; Schenker, S and Dewettinck, $\mathrm{K}$ (2016). The contribution of modern margarine and fat spreads to dietary fat intake. Comprehensive Reviews in Food Science and Food Safety, 15: 633-645.

Patel, AR; Nicholson, RA and Marangoni, AG (2020). Applications of fat mimetics for the replacement of saturated and hydrogenated fat in food products. Current Opinion in Food Science, 33: 63-68.

Rodriguez, A; Castro, E; Salinas, M C; López, R and Miranda, M (2001). Interesterification of tallow and sunflower oil. J. Amer. Oil Chem. Soc., 78: 431-436.

Roseli, N H and Akhir, M F (2019). Temperature variability caused by internal tides in the coastal waters of east coast of Peninsular Malaysia. Acta Oceanologica Sinica, 38: 22-31.

Saadi, S; Ariffin, A A; Ghazali, H M; Miskandar, M S; Abdulkarim, S M and Boo, H C (2010). Effect of blending and emulsification on thermal behaviour, solid fat content, and microstructure properties of palm oil-based margarine fats. J. Food Science, 76: C21-C30.

Seriburi, V and Akoh, C C (1998). Enzymatic interesterification of lard and high-oleic sunflower oil with Candida antarctica lipase to produce plastic fats. J. Amer. Oil Chem. Soc., 75: 1339-1345.

Shin, J A; Akoh, C C and Lee, K T (2010). Enzymatic interesterification of anhydrous butterfat with flaxseed oil and palm stearin to produce low-trans spreadable fat. Food Chemistry, 120: 1-9.

Silva, R C; Cotting, L N; Poltronieri, T P; Balcão, V M; De Almeida, D B; Goncalves, L A G; Grimaldi, $R$ and Gioielli, L A (2009). The effects of enzymatic interesterification on the physical-chemical properties of blends of lard and soybean oil. LWT Food Science and Technology, 42: 1275-1282.

Sivaruby, K; Enamul H M; Miskandar, M S and Spowage, A (2013). Investigating the effect of deforming temperature on the oil-binding capacity of palm oil based shortening. J. Food Engineering, 118: 90-99.

Szczesniak, A S (2002). Texture is sensory property. Food Quality Prefer, 13: 215-225.

Soronja-Simovic, D; Seres Z; Nikolic, I; Simurina, O; Djordjevic, M and Maravic, N (2017). Challenges related to the application of high and low trans margarine in puff pastry production. J. Food Processing and Preservation, 41: e13265.

Tang, H D K (2019). Climate change in Malaysia: Trends, contributors, impacts, mitigation and adaptations. Science of the Total Environment, 650: 1858-1871.

Tang, T S (2002). Fatty acid composition of edible oils in the Malaysian market with special reference to trans-fatty acids. J. Oil Palm Res. Vol. 14: 1-8.

Tang, D and Marangoni, A G (2007). Modeling the rheological properties and structure of colloidal fat crystal networks. Trends in Food Science and Technology, 18: 47483.

Tekin, A; Cizmeci, M; Karabacak, H and Kayahan, M (2002). Trans FA and solid fat contents of margarines marketed in Turkey. J. Amer. Oil Chem. Soc., 79: 443-445.

Thais, S; Daniel, A and Ana, P B R (2020). Physicochemical profile of commercial margarines marketed in Brazil and the impact of trans fatty acid elimination. Authorea. DOI:10.22541/ au.158880314.48849522

Vithanage, C R; Grimson, M J and Smith, B G (2009). The effect of temperature on the rheology of butter, a spreadable blend and spreads. J. Texture Studies, 40: 346-369.

Vucic, V; Arsic, A; Petrovic, S; Milanovic, S; Gurinovic, M and Glibetic, M (2015). Trans fatty acid content in Serbian margarines: Urgent need for legislative changes and consumer information. Food Chemistry, 185: 437-440.

Willett, W C; Stampfer, M J; Manson, J E; Colditz, G A; Speizer, F E; Rosner, B A; Hennekens, C H; Hennekens, C H; Willett, W C; Stampfer, M J; Colditz, G A; Willett, W C; Sampson, L A and Rosner, B A (1993). Intake of trans fatty acids and risk of coronary heart disease among women. The Lancet, 341: 581-585. 
WHO (2019). Countdown to 2023: WHO report on global trans fat elimination 2019. World Health Organisation (WHO). https://apps.who.int/iris/ handle/10665/331300.

WHO (2020). REPLACE: Trans fat-free by 2023. World Health Organisation (WHO). https: / / www. who.int/nutrition/topics / replace-transfat, accessed on 22 April 2020.
Yılmaz, E and Ogutcu, M (2015). Oleogels as spreadable fat and butter alternatives: Sensory description and consumer perception. RSC Advances, 5: 50259-50267.

Young, N W G and Wassell, P (2019). Margarines and spreads. Food Emulsifiers and Their Applications (Hasenhuettl, G L and Hartel, R W eds.). Springer International Publishing. p. 379-405. 